\title{
Towards a Sustainable Vocational Career
}

\author{
MARZENA FRYCZYŃSKA \\ Institute of Human Capital, Collegium of Business Administration, \\ SGH Warsaw School of Economics
}

\begin{abstract}
The goals of sustainable development set priorities for a broad range of stakeholders, i.e. individuals, organisations, societies, and states. They translate into career management priorities, with a view to making careers sustainable. The article presents the preliminary results of the analysis of the concept and the range of meanings of a sustainable career. As a result of a critical analysis and the placement of this concept in the area of management and quality, the assumptions and the definition of a sustainable vocational career were formulated, indicating that it is a sequential arrangement of personal work and outof-work experience related to the performance of work that make it possible to retain physical and mental health and to match competences in a manner enabling productive and meaningful work over a long period.
\end{abstract}

Keywords: sustainable development, career, sustainable career, sustainable working career

JEL Classification Codes: M12, I3, J62 


\section{Introduction}

Employees' careers are the area of interest of e.g. human resources management, organisational behaviour, organisational psychology, and andragogy. In this article, a sustainable career will mainly be presented as an organisational behaviour, as it is assumed that a career is "the evolving sequence of a person's work experience over time" (Arthur et al., 1989, p. 8), which does not mean that no reference will be made to human resources management. The author assumes that organisations are able to implement sustainable organisational careers if they are aware of what such sustainability means for employees, which is the subject of this article, and what legal and institutional solutions could support their internal standards and good practices. So far, Polish publications have been identifying human capital as a factor for implementing sustainable business (Hilarowicz, 2015), characterising it as sustainable personnel, (Pabian, 2011), and indicating sustainable human resources management (Pabian, 2015) and typical organisational practices (Król\&Winnicka-Wejs, 2009; Zaleśna \& Wyrzykowska, 2015; Pocztowski, 2016). However, there is a gap when it comes to the identification of sustainable careers with an agent approach, in which employees are the 'creators' of their own careers, and this is the gap this article intends to fill. Thus, the objective of this article is to identify the characteristics of sustainable careers in the literature, to assess critically the approaches and concepts developed to date, and to present the author's own proposal for a sustainable career.

\section{Careers in the context of sustainable development priorities}

According to the priorities set by the United Nations, global development should enable to meet the needs of the present without compromising the ability of future generations to meet their own needs. The need to comply with this standard affects decisions of international organisations, states, enterprises, and individuals.

Four of the Sustainable Development Goals are related to professional careers, namely:

Goal 3. Ensure healthy lives and promote well-being for all.

Goal 4. Ensure inclusive and equitable quality education and promote lifelong learning opportunities for all.

Goal 5. Achieve gender equality and empower all women and girls.

Goal 8. Promote inclusive and sustainable economic growth, employment and decent work for all. 
These goals refer to the enormous challenges of shaping and managing careers, also sustainable careers, including: the changeability of careers in particular generations, reconciling work and out-of-work roles, the extending working life, matching personal capacities (e.g. health, competences) to labour market requirements, doing a job corresponding to one's personal values and objectives, access to work that is meaningful and valuable to the individual, the community, and the economy. Pursuing the goal of increasing the intensity of sustainable careers requires reformative and adaptive activities of individuals, enterprises, states, and international organisations, which emphasises even more the complexity and multidimensionality of this phenomenon.

\section{Analysing the range of meanings of a sustainable career}

The concept of a sustainable career appears in the literature as response to challenges related to the generational management of human resources. In the first works, K.L. Newman (2011) points out that a sustainable career is a response to challenges related to managing the youngest and the oldest generations on the labour market, i.e. Generation Y and the Boomers. Sustaining productivity, especially in these two groups, is possible by ensuring that three sustainable career requirements are met, namely:

- renewability, which supports longer working lives and life balance;

- flexibility, which enhances resiliency to changes throughout the career; and

- integration and integrity at different stages of the career.

The need for renewability stems from the preceding long or intensive work activity. The assumption is that a person taking a break from their work or becoming involved in a very different activity will not only reinvigorate themselves but will also be more eager to resume their work and work productively. As the course of careers is becoming increasingly changeable, and so is work and the environment, flexibility is growing in importance - a feature that enables employees to adapt to changes, but also anticipate them. Irrespective of any changes, the goal is to sustain employability, which should encourage continuous learning and looking for opportunities or sources of support. The need for integrity and integration, in turn, is a derivative of the integration of personal values and professional activities and the need to give meaning to changes occurring in one's career, in particular in the long term.

A broader catalogue of distinctive features of a sustainable career was proposed by Kossek et al. (2014) in a number of publications:

- sufficient security to meet economic needs;

- matching one's core career and life values; 
- flexibility and capability to evolve to suit one's changing needs and interests;

- renewability, i.e. regular opportunities for rejuvenation.

The characteristic that makes this list different from Newman's proposal (2011) is sufficient security to meet economic needs. It is particularly important in the case of changes in the career that involve a lower income and thus raise concerns about the satisfaction of the material needs of the individual and their close ones, e.g. reconciling work with taking care of weaker family members or shortening the working time. The authors believe that such a career provides positive work experiences over a long period of time and supports individual and organisational effectiveness.

Yet another approach to sustainable career assumes a successful integration of one's personal, family, and work life that provides a sense of security and wellbeing (Greenhaus \& Kossek, 2014). A sense of security is guaranteed not by social security, but employability, i.e. having a job and adapting to the changing labour market requirements or securing employment opportunities in the future. According to the authors, well-being is physical and mental health that should be protected and secured against deterioration or loss. This approach could be summarised as a happy life with a good job, although it is worth emphasising the importance that the authors attach to employability. Employability, i.e. personal ability to perform work, guarantees security and thus reduces tension and anxiety about the changing environment and changes in one's personal and working life.

The framework for the scientific discussion of sustainable careers in the Handbook of Research on Sustainable Careers (2015, p. 7) was its working definition encompassing four main components, i.e.: "sequences of career experiences reflected through a variety of patterns of continuity over time, thereby crossing several social spaces, characterised by individual agency, herewith providing meaning to the individual".

The time component is expressed e.g. in the sequentiality and changeability over time of various work-related experiences or the lengthening of the period of professional activity before retirement. Sustainable careers are careers pursued in various workplaces, even at the same time, and providing an individual with many options for new activities. The essence of individual agency is that it is the employee and not the organisation that 'owns' the employee's career, with all the chances and threats that may arise. The meaning, in turn, stems from the need to make choices in your work and out-of-work life in accordance with your personal values or career anchors. Thus, at this stage of their research, the authors indicate some career areas without specifying the qualitative characteristics of a sustainable career. S. De Hauw and J. Greenhaus (2015, p. 224), in turn, define a sustainable career as "as a career in which employees remain healthy, productive, happy and employable throughout its course and that fits into their broader life context". 
If we assume that a career is the 'personal business' of each employee and is retrospectively characterised by sequences of work-related experiences, then the question arises, how is a sustainable career pursued? According to the authors, taking advantage of opportunities and facing their broad portfolio, employees decide on each next experience themselves or internalise decisions of other people that change their work. To have a career that is sustainable, i.e. one that guarantees security and well-being, an employee seeks to adapt appropriately the contents and conditions of their work. Changes in responsibilities and the number and types of tasks (contents) are made by referring to one's own experiences, values, and priorities. Their direction and intensity vary over the course of the entire career, which is noticeable especially when the employee takes responsibility for building a sustainable career. Another area of change through which a career can be shaped involves changes in the working time and the workplace, continuity vs. breaks in professional activity, and changes in the contract regulating employment (working conditions). By taking into consideration these seven dimensions of determining work characteristics, it is possible to personalise careers. However, an employee may make multiple decisions concerning these dimensions that will defy a sustainable career. This approach emphasises the agency of an employee in managing their own career; an employee changes the sequence of their work experiences by changing their job and its characteristics.

In another publication of these authors (De Vos et al., 2018), consolidating the analysis presented in the Handbook of Research on Sustainable Careers, a sustainable career is a career that provides mutual benefits for the individual and their broader context, taking into account the long-term perspective. Their conceptual model of a sustainable career (De Vos et al., 2018) refers to individuals, encompassing many diverse factors making it possible to distinguish a sustainable career from a nonsustainable career (systemic approach) and introduces the time variable to moderate the quality of career sustainability over time (dynamic approach). Although the authors propose analysing careers as individual trajectories spanning an entire lifetime, they indicate the broad context of the environment in which individuals pursue their careers. Benefits for a sustainable career should be analysed with respect to the individual, their family and close ones, the organisation, and society as a whole. And although the authors do not point directly to the effects of a sustainable career, a hint can be taken from factors informing about the intensity of career sustainability, i.e. health, happiness, and productivity. A career is the more sustainable, the more it enables a person to preserve their physical and mental ability (health), to be satisfied with their career, while taking into account other areas affecting work (happiness), and to achieve results in the current workplace and enhance their career potential and employability (productivity). 
When it comes to the factors of a sustainable career, a number of benefits derived by an individual and their broad context can be identified. Maintaining health for long years enables an individual to work, which, under the conditions of the employee's market and deficits in certain professions, gives a chance for achieving the objectives of the organisation, guarantees income for the employee and their close ones, and increases state revenues due to additional revenues from work and lower costs related to health services (preventive healthcare is less costly) and rehabilitation and pension benefits. Loss of health, on the other hand, and the resultant inability to pursue a sustainable career, means costs of absenteeism borne by employers - sickness benefits and lost profits from the employee's work, costs of treatment borne by the employee with a lower income, and costs borne by the healthcare system, as well as the inability to perform out-of-work roles and increasing alienation, especially in the case of serious and chronic diseases. An employee's satisfaction with their own career indicates that the employee has achieved their objectives, which, in the assumed majority, are formulated as mobilising and not restricting activity. Career objectives are connected with an individual's own preferences and values and their achievement gives a sense of success and happiness. If this is so, we deal with the fulfilment of individual potential. Pursuing a career with satisfaction, when it is also possible to perform other roles and function in other areas of life, brings a range of benefits to employees and the recipients of their activity, e.g. parents, children, friends or a local association. Employees perform various activities (e.g. they do voluntary work, educate their children or take care of the elderly) which, as a result, do not need to be performed by public or social welfare institutions and thus relieve their burden, reducing state expenditure. Job satisfaction is an important indicator of productivity, which is financially advantageous to all beneficiaries of such enhanced performance - the employee, their dependants, the organisation or the state. As S. De Hauw and J.H. Greenhaus et al. (2015, p. 224) summed up: "being healthy and happy is thus an important prerequisite for employees' long-term performance, as it gives them the necessary energy and drive to work effectively throughout the course of their career".

Productivity at work is the classic result of performed work that gains a broader sense in a sustainable career. Two additional components are indicated: first, performing given work in a specific manner to increase the potential for performing other types of work that are or will be in demand on the labour market. Second, productivity understood in this way assumes the fulfilment of an individual's potential, which increases the use of the available human capital for the purpose of delivering value. With productivity understood in this way, capital of the highest available quality is used, and the value of that capital is increased through work and secured for future projects and work activities. Thus, we can speak of the increasing 
value of the human capital of an organisation and the entire society. Operating while using a higher and not lower quality of the available human capital brings additional benefits to employees, the organisation, and the society. On the other hand, work performed below the competences and expectations is only half-productive as the potential benefits are lost. Another issue is the securing of future productivity by adapting competences to future requirements and ensuring a workload that simultaneously generates benefits for the present and for the future, which, in the case of a young employee, can mean the next fifty years.

This approach emphasises the basic objectives of sustainability, i.e. the creation of something that is valuable not only to a given entity (the Earth, a country, an organisation, an individual) and its environment at a given time, but also to future generations. In terms of sustainable careers, transferring (or at least not limiting) benefits to future generations is understood as the long-term perspective, although when analysing careers as individual trajectories of work activity, we can understand the 'long-term perspective' as the lengthening of the work activity of individuals before retirement and as remaining professionally active for a long time after retirement. In sustainable careers, transferring benefits to future generations is related to combining one's professional role with their parental role.

An elaboration of K.-L. Newman's concept (2011) was proposed by T. Chin et al. (2019), who, on the one hand, adopt the three core dimensions of a sustainable career and, on the other hand, extend them with another dimension - resourcefulness. Such an extension is particularly important for production workers from industries implementing technological innovations and robots with artificial intelligence. The current technological changes raise concerns about job losses on the one hand, and increased job requirements on the other hand - employees need new resources (knowledge, competences, organisational support, additional sources of income) and quick access to such resources. Thus, renewability, flexibility, and integration make it possible to achieve a sustainable career, but only if, at the same time, employees resourcefully secure their needs and resources. As the authors point out, without resourcefulness, this particular group of workers in China will not be able to pursue a sustainable career. In accordance with the principle of agency, it is the employee who manages his or her own career and is responsible for its course. However, transformation into Industry 4.0 is a systemic change that requires solutions also at the level of states and international organisations, which should ensure that employees can pursue sustainable careers. In such conditions, the bottom-up resourcefulness of individual employees may be insufficient.

An analysis of the frequency of words used to define a sustainable career in English publications indicates that so far authors have primarily been adopting the agent approach, that of a person (broader than an employee) integrating with 
their out-of-work life. The frequently used word, 'career', referred to the length of one's working life, career values, and career-related (work) experiences. Apart from the verbs indicating action-related relationships between words, a sustainable career also concerns the areas of change, flexibility, needs, renewability, and security.

Figure 1. Analysis of words defining a sustainable career

\section{individual integrity life

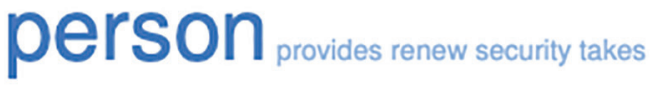

Source: own work based on: https://tagcrowd.com

The analysis was performed on six definitions and the accompanying descriptions of a sustainable career, after the expression studied was deleted. Only words that appear at least twice were visualised and presented in Figure 1.

\section{Towards a sustainable vocational career}

The basic assumption of sustainable development is that meeting the needs of the present does not compromise meeting the needs of the next generations, which should be reformulated in the context of careers. The main object of interest is a person who develops, matures, acquires proficiency, and eventually grows old as time passes. Thus, the next generations can be understood in two ways: 1/ in a broader sense, as stages of one's life and career or 2/ in a narrower sense, as subsequent work activities. A sustainable career in the broader sense secures the satisfaction of the needs of the present and future stages of one's life and career. In the narrower sense, the present work activity in one or more workplaces at least does not limit, despite ageing processes, the ability to perform work in the future.

A sustainable career in which work and out-of-work life are integrated and are a source of satisfaction for the individual encourages the reflection that we can speak of a sustainable life. However, in the context of management, it is important to associate sustainable careers much more strongly with work experiences, which 
can be gained only in organisations - workplaces. For the purposes of this article, it is assumed that a sustainable vocational career is a sequential arrangement of personal work and out-of-work experiences related to the performance of work that make it possible to retain physical and mental health and to match competences in a manner enabling productive and meaningful work over a long period. The adoption of this definition involves a range of assumptions, synthetically indicated below, that require empirical verification:

- responsibility and proactivity of individuals in shaping their own careers as sustainable;

- providing individuals with regular opportunities for physical and mental rejuvenation and for acquiring the necessary competences;

- education and social security systems supporting the maintenance of physical ability, competence matching, and work activity;

- identifying a working career from a long-term perspective; inclusion in work activity both at the early and the late stage of life;

- varying engagement in work and out-of-work activities over the course of one's working career;

- maintaining a balance between work activity and engagement in other (out-ofwork) areas of activity;

- flexibility in adapting the scope, contents, and conditions of work to the changing needs and values of employees and employees' adaptation to the requirements of the labour market;

- integration of changes occurring in one's work activity, arising from changes in personal needs and values and in external conditions;

- identifying sustainable careers through personal effects occurring at the same time, i.e. well-being, productivity, and employability, and through non-personal effects, i.e. organisational and social effects.

\section{Conclusion}

This article has outlined the issue of employees' careers in the broader context of sustainable development and sustainable management of organisations and human resources. The dominant position was taken by the analysis of scientific publications presenting the concept and the range of meanings of a sustainable career. Not many studies have been published so far; the oldest ones date from 2011. They describe sustainable careers mainly based on the concept of an individual's agency. The publications are theoretical studies indicating a strong need for empirical verification. As a result of the performed analysis of the contents and 
word frequency and due to the need to embed this research area in management and quality sciences, the author proposed the concept of a sustainable career, emphasising the dominant role of productive and meaningful work experiences from a long-term perspective, and outlined derivative areas requiring further analysis. Thus, the article opens up scope for further research, for testing assumptions and formulating epistemological conclusions.

\section{References}

Arthur, M.B., Hall, D.T., \& Lawrence, B.S. (1989). Handbook of career theory. Cambridge: Cambridge University Press.

Chin, T., Li, G., Jiao, H., Addo, F., \& Jawahar, I.M. (2019). Career sustainability during manufacturing innovation. A review, a conceptual framework and future research agenda. Career Development International, 24(6), 509-528.

De Hauw, S, \& Greenhaus, J. (2015). Building a sustainable career: the role of workhome balance in career decision making. In: A. De Vos, B.I.J. M. Van Der Heijden (Eds.). Handbook of research on sustainable careers. Cheltenham: Edward Elgar Publishing, 223-238.

De Vos, A., Van der Heijden, B., \& Akkermans, J. (2018). Sustainable career: Towards a conceptual model. Journal of Vocational Behavior, Retrieved from: https://doi. org/10.1016/j.jvb.2018.06.011 (accessed: 2.10.2019).

Greenhaus, J.H., \& Kossek, E.E. (2014). The contemporary career: A work-home perspective. Annual Review of Organizational Psychology and Organizational Behavior, 1(1), 361-388.

Hilarowicz, A. (2015). Rola i znaczenie kapitału ludzkiego w koncepcji sustainability. Zeszyty Naukowe Politechniki Śląskiej. Organizacja i Zarządzanie, 85, 141-152.

Kossek, E.E., Valcour, M., \& Lirio, P. (2014). The sustainable work force: Organizational strategies for promoting work-life balance and well-being. In: P.Y. Chen and C.L. Cooper (Eds.), Work and Well-being: Well-being: A Complete Reference Guide. Volume III. Hoboken: John Wiley \& Sons, 295-319.

Król, M., \& Winnicka-Wejs, A. (2009). Społecznie odpowiedzialne inwestowanie w kapitał ludzki. Prace i Materiały Wydziału Zarzq̨dzania Uniwersytetu Gdańskiego, 3/2, 223-235.

Newman, K.L. (2011). Sustainable careers: Lifecycle engagement in work. Organizational Dynamics, 40(2), 136-143.

Pabian, A. (2011). Sustainable personnel - pracownicy przedsiębiorstwa przyszłości. Zarządzanie Zasobami Ludzkimi, 5, 9-18.

Pabian, A. (2015). Zrównoważone zarządzanie zasobami ludzkimi - zarys problematyki. Zeszyty Naukowe Politechniki Częstochowskiej, 17, 7-16.

Pocztowski, A. (2016). Zrównoważone zarządzanie zasobami ludzkimi w teorii i praktyce. Zarządzanie i Finanse, 14(2), part1, 303-314. 
Van der Heijden, B.I.J. M., \& De Vos, A. (2015). Sustainable careers: Introductory chapter. In: A. De Vos, B.I.J. M. Van Der Heijden (Eds.), Handbook of research on sustainable careers. Cheltenham: Edward Elgar Publishing, 1-19.

Zaleśna, A., \& Wyrzykowska, B. (2015). Zrównoważone zarządzanie zasobami ludzkimi w praktyce przedsiębiorstw w Polsce. Organizacja i Kierowanie, 75(1), 151-165.

\section{Marzena Fryczyńska}

Works in the Institute of Human Capital of Collegium of Business Administration as Professor of SGH Warsaw School of Economics. Her scientific interests focus on the assessment and development of competences, career management, networking and leadership. She investigates problems individually and in cooperation with scientists from Poland and abroad. She delivers lectures and serves as the manger of postgraduate studies: 'Human Capital Management' and 'Academy of Leadership in English'.

e-mail address: mfrycz@sgh.waw.pl

ORCID: 000-0001-5882-7017 